\title{
Study on the Mechanism of Entrepreneurial Social Capital Affecting the Diversification and Risk of Chinese Enterprises
}

\author{
Fulei Wei ${ }^{1,2, a}$, Xiaofeng $\mathrm{Ju}^{1}$ \\ ${ }^{1}$ Harbin Institute of Technology, Harbin, 150001, China; \\ ${ }^{2}$ Heilongjiang University of Science and Technology, Harbin, 150027, China. \\ aweifulei2006@126.com
}

Keywords: entrepreneurial social capital, diversification, risk.

\begin{abstract}
As a special resource, the entrepreneurial social capital is not only an important motive for the diversification of enterprises, but also can effectively regulate the risk caused by diversification. Considering the relationship social and transition economy background of China, the effect of the entrepreneurial social capital on diversification and risk is more obvious. And it has important value to study the mechanism how entrepreneurial social capital affects the diversification and risk of Chinese enterprises.
\end{abstract}

\section{Introduction}

Diversification is one of the focus issues in theoretical research. And many enterprises have experienced the process from diversification to refocusing strategy in practice. Although the diversification practice of many enterprises have failed and many scholars question the effect of diversification, diversification remains popular in practice and many world's top 500 enterprises also remains moderate diversification [1]. Strategy related to the survival of the enterprise, and entrepreneurs play an important role in the selection of strategy, so entrepreneurial social capital as important resource have direct impact on enterprise strategy.

Therefore, it has great significance to study the relationship between diversification and risk from the viewpoint of entrepreneurial social capital, and explain the motivation of diversification and the mechanism of risk aversion.

\section{Entrepreneurial social capital and its function}

\subsection{Entrepreneurial social capital}

China is a relational society, and the network of social relations plays an important role in the social life and economic life of individuals. Fei Xiaotong (1947) describes the social relationship networks which related by blood, kinship and geography in traditional Chinese society by the concept of "Diversity-orderly Structure" [2]. Although it has taken palce great changes in Chinese society, the social soil with "Diversity-orderly Structure " still exists.

Entrepreneurs built their own social networks through various channels for the development of enterprises. And entrepreneurial social capital is resources that embed in the relationship network of entrepreneurs, and it represents the ability to obtain resources such as capital, talent, technology etc. Entrepreneurial social capital has become an important part of entrepreneur human capital. Entrepreneur's social network includes stable link established through various groups, associations and other social organizations, and individual social network built relying on blood, kinship, geographical $[3,4,5]$.

\subsection{The function of entrepreneurial social capital}

The function of entrepreneurial social capital can be divided into two categories: non instrumental and instrumental function. On the one hand, entrepreneurs established trust and cooperative relations with stakeholders through social network to promote interaction between each other, and create favorable external development environment, this is the non instrumental function. On the other hand, entrepreneurs can obtain resources such as policy, capital, information, technology, knowledge 
through social network, and promote dynamic capability, save transaction costs, enhance competitiveness; this is its instrumental function [6].

\section{Mechanism of entrepreneurial social capital effecting diversification and risk}

General speaking, Entrepreneurs built social relationship network which includes social organization network and private networks, and obtain resources such as policy, capital, technology, information by their mobilization ability. Then they transform the resources into the dynamic capabilities through the internal integration mechanism of enterprise, which supply the basis of diversification for enterprises. And enterprises will carry out diversification driven by a series of motivations. Diversification can lead to potential risks such as environment, resources, finance, and management etc. But entrepreneurial social capital can regulate the risk, and reduce or even resolve the potential risks caused by diversification to some extent. The mechanism is showed in Fig 1.

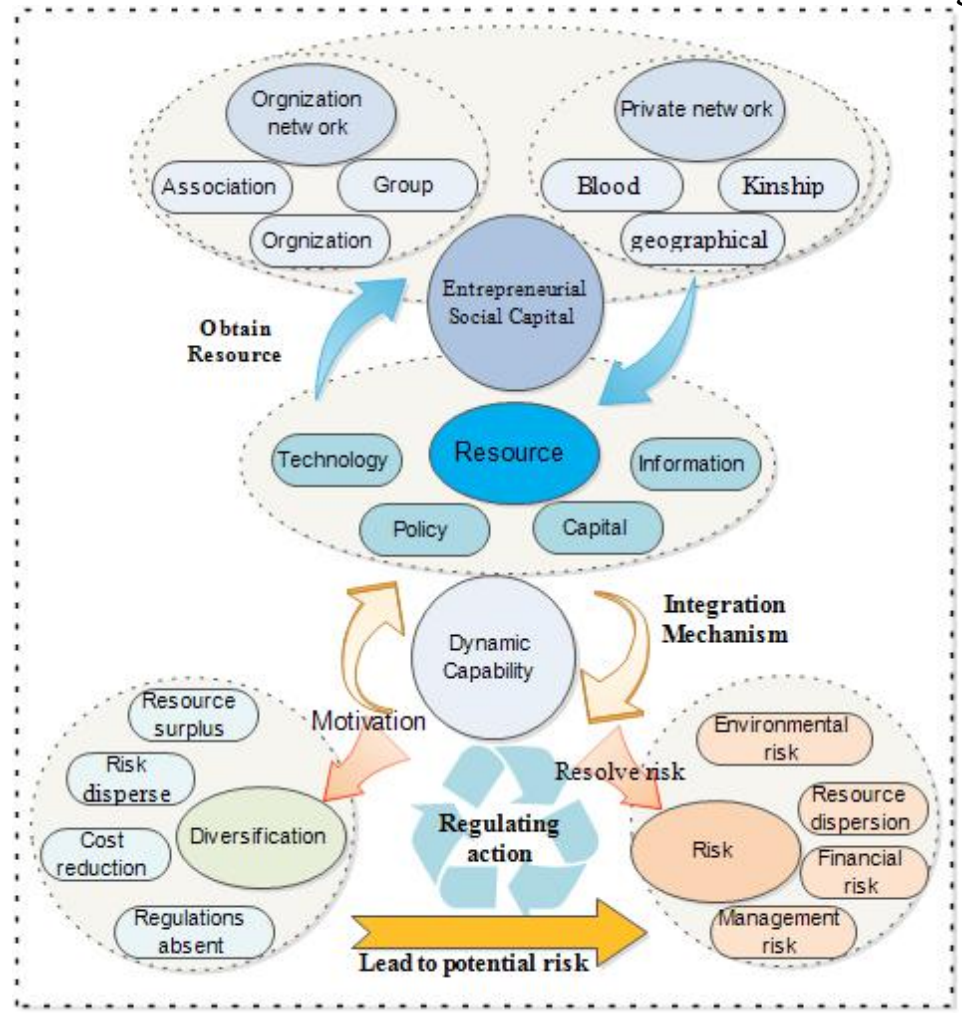

Fig. 1 Mechanism of entrepreneurial social capital effecting diversification and risk

\subsection{The mechanism of entrepreneurial social capital driving the diversification of enterprise} As the heterogeneity characteristics of entrepreneur, the entrepreneurial social capital has important influence on the decision of diversification strategy. According to relevant theories, the reasons that entrepreneurs use their social capital to obtain resources and carry out diversification can be attributed to the following aspects.

(1) The impact of institution transition in transition economy period. As the external environment, the institution has important influence on the strategic choice of enterprises. And the institutional environment is an important explanation for the diversification strategy of enterprises in various countries. Khanna and Palepu (1997) pointed out that the market mechanism of emerging market countries is not perfect; and enterprises tend to select diversification to make up the absent of external market through internal market allocation [7]. Peng (2002) considered that strategy not only depends on industry condition and special resources, but also depends on the special institutional environment decision maker faced $[8,9]$. Since the reform and opening up, China has begun to transition from planned economy to market economy. Institution change has brought more investment opportunities for enterprises in the transition economy period. However, the entry threshold of some industries is high, and the private enterprises are difficult to enter the monopoly industries. But, entrepreneurs with more social capital are more likely to get the industry permission, 
and obtain high profits through diversification. At the same time, there is also lack of institution and instability in the transition process, so the development of enterprises is facing greater uncertainty. Entrepreneurs usually hedge the risk through built social network and carry out diversification. Additional, the government controls many resources in the transition process, and the diversification of some enterprises is just in order to meet the performance needs of local officials.

(2) Make full use of resources. Penrose (1959) believed that resources are the power source of enterprise growth, and the surplus resources can be effectively used to promote the growth of enterprises through diversification [10]. Now, resource theory has become an important theoretical basis of diversification. When the enterprise has surplus resources, and diversification can achieve the maximum profit, it will choose the diversification strategy [11].

(3) Risk disperses. According to the portfolio theory of Markowitz (1952), investors can effectively disperse risk through a reasonable portfolio. This theory is also applies to enterprise. In order to disperse operation risk, entrepreneurs will consider diversification when they have certain social capital. Additional, according to the principal-agent theory, the separation of ownership and management in modern enterprises leads to manager's adverse selection and moral hazard [12]. Under the principal-agent system, managers can't avoid their professional risk through investment portfolio as investors. Therefore, in order to disperse their own risk, managers will use their social capital to implement diversification which can improve their reputation, consolidate their position and reduce the risk of dismissal [13].

(4) Cost reduction. Transaction cost theory is proposed by Coase (1937), which refers to the cost of trading activities through the open market exchange. Based on transaction cost theory, Williamson $(1975,1985)$ pointed out that the internal market can be replaced by the external market to save external transaction costs through diversification, at the same time the internal cost will increase, so the effect of diversification depends on the level of two kinds of cost. For entrepreneurs, the internal problems are relatively easy to solve. Therefore, when facing the game between internal and external transaction costs, entrepreneurs tend to reduce the external transaction costs by vertical integration of industry chain through diversification. Of course, the entrepreneurial social capital is a very critical support condition in this process.

\subsection{Potential risks resulting from diversification.}

Diversification strategy has a very high application value. But many enterprises implement diversification was failure. Diversification is a double-edged sword, which also brings some potential risks.

(1) Environmental risk. The external environment of the enterprise is complex. The change of many factors such as politics, economics, society and technology bring uncertainty to the development of enterprise, and constitute the environmental risk of enterprise. The risk enterprise faced will increase with the level of diversification.

(2) Resource dispersion. Enterprises need to reallocate resources when implement diversification. Enterprises distribute original quality resources to various sectors, and new resources can't be added quickly. If not handled properly, not only new business can't operate smoothly, but also the performance of original core business will be impact. As a result, the competitiveness of enterprise will decrease.

(3) Resource dispersion. Enterprises need to reallocate resources when implement diversification. Enterprises distribute original quality resources to various sectors, and new resources can't be added quickly. If not handled properly, not only new business can't operate smoothly, but also the performance of original core business will be impact. As a result, the competitiveness of enterprise will decrease.

(4) Management risk. Diversification will increase the difficulty of the integration of internal management. On the one hand, diversification leads many problems such as the increase of organizational structure, reduction of management efficiency, and increases of the decision making risk.

On the other hand, the original management mode of the enterprise is not applies to the new business, and it's easy to lead to management risk. 


\subsection{Mechanism of entrepreneurial social capital impact on enterprise risk}

Avoiding risks is one of the important aims that entrepreneurs build social networks. The entrepreneurial social capital provides a solid foundation for the enterprise to strengthen its dynamic capability. Based on strong social capital and dynamic capability, enterprises can better deal with risk. The influence of social capital on risk runs through the whole process of enterprise management.

(1) Strict feed forward Control. The entrepreneurial social capital contains lots of political, economic, social and technological resources, and they're integrated into the daily operations of enterprise. So enterprise can control the source of risk effectively, and eliminate the risk in the bud.

(2) Fast response to block the spread of risk. Social capital enables entrepreneurs to have rich knowledge reserves and fast information channel. Therefore, for the changes of environment, resources allocation, and management, entrepreneurs can make a quick response and interrupt the spread of risk, which can solve the problems before the crisis is expanded.

(3) Powerful intervention to eliminate the impact of risk. In many cases, enterprise has the ability to deal with risk, and the risk event is not enough to cause the destruction of the enterprise.

However, many enterprises collapsed in the risk events. The key point is that enterprise lose the best time to deal with the crisis because the interception of stakeholders. And the entrepreneurial social capital can solve this problem to a great extent. Entrepreneurs establish mutual beneficial relationship and mutual trust with different government departments, enterprises and other stakeholders in the process of establishing social relation network. Even if the enterprise suffers crisis events, it's also easier to get support from stakeholders, so that enterprise can eliminate the risk and survival.

\section{Summary}

As the special resource of enterprise, entrepreneurial social capital has important value to the operation of enterprise. Especially in the social environment of China's relationship and transition economy period, the role of entrepreneurial social capital is more prominent. The entrepreneurial social capital is not only an important motive for the diversification of enterprises, but also can effectively regulate the risk caused by diversification. The effect of the entrepreneurial social capital on diversification and risk is more obvious. And it has important value to study the mechanism how entrepreneurial social capital affects the diversification and risk of Chinese enterprises.

\section{Acknowledgements}

This paper is support by the Ministry of education of Humanities and Social Science project (Grant No.13YJA630088), and Heilongjiang Philosophy and Social Science Foundation (Grant No.15GLD04).

\section{References}

[1] Yang Qiang, Wang Bo, Lv Rongsheng. Study on motivation and venture of diversification strategy, J. Journal of Beijing Jiaotong University (Social Sciences Edition), 2008, 7(3), pp. 85-88.

[2] Fei Xiaotong. Earthbound China, Peking University press, Beijing, 2012.

[3] Bian Yanjie, Qiu Haixiong. The social capital of enterprises and its efficiency, J. Chinese social sciences, 2000 (2), pp. 87-99

[4] Chen Chuanming, Zhou Xiaohu. Some thoughts on the entrepreneurial social capital, J. Social sciences in Nanjing, 2001(11), pp.1-6.

[5] Wei Hong, Chen Chuanming. An analysis of the concept and connotation of Entrepreneurial Social Capital -Based on the social context of China, J. Modern management science, 2014(2), pp. 3-5. 
[6] Bian Yanjie, Wang Wenbin et al. Institution-crossing social capital and its income returns, J. Chinese social sciences, 2012 (2), pp. 110-126.

[7] Khanna T., K. Palepu. Why Focused Strategies May be Wrong for Emerging Markets, J. Harvard Business Review, 1997(7-8), pp. 41-51.

[8] Mike W. Peng. Towards an Institutional-Based View of Business Strategy, J. Asia Pacific Journal of Management, 2002(19), pp. 251-267.

[9] $\mathrm{Yu}$ Kexin, Xie Peihong. A study on the institutional roots and paradigm construction of diversification management of Chinese enterprises in the transition period, J. Management world, 2011 (7), pp. 180-181.

[10]Penrose E G. The theory of the growth of the firm, New York: Wiley, 1959.

[11]Liu Qiong, Deng Yazhong. Theories and future prospects of enterprise diversification based on resource-based view, J. Journal of Yunnan University of Finance and Economics, 2015(2): pp. 82-89.

[12]Mueller, Dennis C. A Theory of Conglomerate Mergers, J. Quarterly Journal of Economics, 1969, 83 (4), pp.643-659.

[13]Lin Xiaohui. A study on the motivation and performance of diversification of China's listed companies. Xiamen University, Xiamen, 2008. 